\begin{tabular}{|c|c|}
\hline $\begin{array}{r}\text { Contato } \\
\text { Avenida Tancredo Neves, } 6731\end{array}$ & Paulo Renato da Silva* \\
\hline $\begin{array}{r}\text { Caixa Postal } 2044 \\
\text { 5867-970 - Foz do Iguaçu - Paraná - Brasil } \\
\text { E-mail: paulo.silva@unila.edu.br }\end{array}$ & $\begin{array}{l}\text { Universidade Federal da Integração Latino- } \\
\text { Americana }\end{array}$ \\
\hline
\end{tabular}

\title{
MEMÓRIA E HISTÓRIA DE EVA PERÓN
}

Americana

\section{Resumo}

O artigo analisa a construção da memória da primeira-dama argentina Eva Perón (1919-1952). Destacamos que, na Argentina contemporânea, sua memória tem sido reivindicada positivamente por diferentes grupos político-sociais e não apenas pelos peronistas. Contudo, ressaltamos a necessidade de se diferenciar a memória da história de Eva Perón, marcada por tensões inclusive com a base social do peronismo.

\section{Palavras-chave}

Argentina - peronismo - memória.

* Doutor em História pela Universidade Estadual de Campinas. Professor Adjunto II, Departamento de Cultura e Sociedade. 


\author{
Contact \\ Avenida Tancredo Neves, 6731 \\ Caixa Postal 2044 \\ 85867-970 - Foz do Iguaçu - Paraná - Brasil \\ E-mail: paulo.silva@unila.edu.br
}

\section{MEMORY AND HISTORY OF EVA PERÓN}

\section{Paulo Renato da Silva}

Universidade Federal da Integração Latino-

Americana

\begin{abstract}
The article analyzes the construction of the memory of Argentine First Lady Eva Perón (1919-1952). We highlight the fact that in contemporary Argentina her memory has been reclaimed positively by different sociopolitical groups and not only by Peronists. However, we emphasize the need to recall the historical account of Eva Peron, which was characterized by tensions even with the Peronist base.
\end{abstract}

\title{
Keywords
}

Argentina - peronism - memory. 
rev. hist. (São Paulo), n. 170, p. 143-173, jan.-jun., 2014 http://dx.doi.org/10.11606/issn.2316-9141.v0i170pl43-173
Paulo Renato da Silva

Memória e história de Eva Perón

Fanatismo: Defensa entusiasta y fervorosa de la doctrina peronista. Derecho legítimo del pueblo a defender y difundir - hasta con la vida la ciudadanía en marcha.

Eva Perón. ${ }^{1}$

Conquanto poucos os grevistas, o fato dói-me n'alma como se tivessem sido todos.

Eva Perón. ${ }^{2}$

Perón y Eva hicieron mucho más que destruir la economía del país. (...). Deshonraron al país y por este cargo los juzgarán las generaciones venideras, que necesitarán (...) recuperar el honor perdido. (...) aquellos que inicien la tarea no deberán subestimar la influencia que "santa Evita" ejerce sobre los corazones simples (...), influencia (...) que desaparecerá, no por medio de leyes ni decretos, sino con ilustración, esperanza y libertad.

Mary Main, $1956 .^{3}$

Los héroes que de una u otra manera mueren por la liberación de los pueblos de América Latina no tienen sepultura: los cadáveres de Evita $y$ del Che no tienen descanso (...). Profanar el tabú, (...) develando el verdadero significado histórico de Evita, haciendo aflorar a la conciencia

el secreto de su poder (...) es una de las maneras (...) de contribuir al esclarecimiento de la conciencia de la clase trabajadora y de las mujeres argentinas (...). Juan José Sebreli, $1971{ }^{4}$

Eva Perón fue una reina de verdad y no una reina del bótox. Elisa Carrió, 2007. ${ }^{5}$

Esta dirigencia traidora del justicialismo, usando el nombre de Perón y Evita, aniquiló el programa pensado por ambos y lo convirtió en un instrumento del ala derecha para llevar a cabo sus propios intereses. Fernando Pino Solanas, $2010 .^{6}$

Eva Perón es un ícono histórico y cultural de todos los argentinos. Cristina Kirchner, 2011. ${ }^{7}$

1 PERÓN, Eva. Por qué soy peronista y las fuerzas espirituales del peronismo. Buenos Aires: C. S. Ediciones, 1996, p. XXXVIII.

2 PERÓN, Eva. A razão de minha vida. Rio de Janeiro: Freitas Bastos, s/d., p. 244.

3 MAIN, Mary. La mujer del látigo. 5ª ed. Buenos Aires: Ediciones La Reja, 1956, p. 199.

4 SEBRELI, Juan José. Eva Perón ¿aventurera o militante? 4ª ed. Buenos Aires: La Pléyade, 1971, p. 112-113.

5 VIDAL, Armando. Eva Perón fue una reina de verdad y no una reina del bótox. Clarín, Buenos Aires, 12/10/2007. Disponível em: <http://edant.clarin.com/diario/2007/10/12/elpais/p-01201. htm>. Acesso em: 23/04/2012.

6 SOLANAS, Fernando Pino. Aniversario del fallecimiento de Eva Perón. Disponível em: <http:// es-es.facebook.com/notes/fernando-pino-solanas/aniversario-del-fallecimiento-de-eva-peron/137880766242774>. Acesso em: 23/04/2012.

7 KIRCHNER, Cristina. Acto de inauguración del retrato de Evita en el ex-Ministerio de Obras Públicas: Palabras de la presidenta de la Nación. Disponível em: <http://www.presidencia.gov. ar/discursos/25273>. Acesso em: 23/04/2012. 
Em 2012, o falecimento da primeira-dama argentina Eva Perón (1919-1952) completou sessenta anos. No entanto, Evita, como era - e é - popularmente conhecida, permanece na política do país. Ora delatada, ora "santificada", a figura de Eva Perón tem sido relida e incorporada a alguns dos principais debates político-culturais da Argentina desde meados do século XX.

Evita está mais presente do que nunca, sobretudo depois que os peronistas Néstor e Cristina Kirchner assumiram a presidência do país em 2003 e 2007, respectivamente. É evidente que governos peronistas destacariam positivamente a atuação da primeira-dama do presidente Juan Domingo Perón (1946-1955/1973-1974). Entretanto, há uma mudança expressiva em curso na memória de Evita. Essa mudança vai além do peronismo. Principalmente desde a crise econômica vivida pela Argentina entre o final do século XX e o início do XXI, Eva Perón tem sido reivindicada por diferentes sujeitos e grupos político-sociais como um símbolo de justiça social e de um Estado protetor, diferente do neoliberal que marcou o país na década de 1990, o qual teria levado os argentinos à crise. Há um desdobramento dessa reivindicação no plano da identidade nacional e do nacionalismo: a primeira-dama aparece como um símbolo de uma época - supostamente - áurea vivida pela Argentina.

Na década de 1970, a vida de Eva Perón se transformou em uma ópera-rock com letra de Tim Rice e melodia de Andrew Lloyd Webber, ambos ingleses. A obra foi encenada nos palcos de Londres e da Broadway. Em 1996, o diretor inglês Alan Parker levou a ópera-rock ao cinema, com a - polêmica - cantora Madonna no papel de Evita. Em 2006, a ópera-rock foi reencenada em Londres, em 2011 no Brasil e estreou novamente na Broadway em 2012.

Em 1994, o diplomata e escritor argentino Abel Posse publicou o romance La pasión según Eva. Em 1995, o jornalista e escritor argentino Tomás Eloy Martínez (1934-2010) publicou Santa Evita, outro romance sobre a primeiradama. O livro se tornou um sucesso editorial internacional. Em 1996, em meio às polêmicas provocadas pelo filme de Alan Parker, sobretudo quanto à escolha de Madonna para viver a "santa Evita", como muitos ainda a consideram, o diretor argentino Juan Carlos Desanzo levou às telas dos cinemas Eva Perón, la verdadera historia. Em 2011, Eva, de la Argentina, um desenho animado sobre a primeira-dama, dirigido pela jornalista argentina María Seoane, foi lançado poucos dias antes da reeleição de Cristina Kirchner. Cartões postais com as imagens de Perón e Evita são encontrados facilmente na capital argentina. O túmulo de Eva Perón no cemitério da Recoleta, em Buenos Aires, é um dos pontos turísticos mais conhecidos da cidade. Em Caminito, outro ponto turístico importante, estátuas de Evita decoram as 
sacadas de algumas casas, ao lado de estátuas de outros argentinos famosos como Maradona, Che Guevara (1928-1967) e Carlos Gardel (1890-1935), o saudoso cantor de tangos. ${ }^{8}$ Apesar de todos esses exemplos - e há outros -, a reivindicação contemporânea de Eva Perón por diferentes sujeitos e grupos político-sociais argentinos não pode ser resumida a um fenômeno da indústria cultural e/ou do turismo. Isso porque existem apropriações bastante particulares e politizadas da memória de Eva Perón.

O objetivo deste artigo é analisar os percursos da memória de Evita, com ênfase no período posterior ao golpe de Estado que derrubou Perón em 1955. Portanto, não analisaremos o período entre 1952, quando faleceu Evita, e 1955, anos marcados por uma intensa propaganda do governo Perón para enaltecer o legado deixado pela primeira-dama. Nesse período, houve "apenas" uma mudança de grau, uma intensificação dos traços que já eram atribuídos a Evita. Interessa-nos analisar as (re)leituras dessa imagem construída feitas posteriormente pelo Estado argentino e por diferentes sujeitos e grupos político-sociais, cujas ações são, muitas vezes, ofuscadas pela imagem estatal e pelo mito que se formou em torno da primeira-dama.

Consideramos que Pierre Nora nos ajuda a percorrer os caminhos da memória de Eva Perón. A construção da imagem de Evita pelo governo de Juan Domingo Perón era indissociável da construção do próprio peronismo. O peronismo se apresentava - e se apresenta - como o "autêntico" defensor dos interesses nacionais e populares: assim, a primeira imagem de Eva Perón era bastante pautada pela simbiose entre Estado, nação e sociedade buscada pelo peronismo. Era, então, uma imagem "oficial". Porém, conforme aponta Nora, a partir da década de 1930 ocorreu o fortalecimento da sociedade. O peronismo inclusive pode ser lido como uma resposta - progressista para alguns, conservadora para outros - a esse fortalecimento. E, segundo Nora, o fortalecimento da sociedade fez com que diferentes sujeitos e grupos étnicos, políticos e ou sociais se apropriassem de histórias e ou memórias de cunho oficial: no caso de Eva Perón, apropriações tanto "positivas" como "negativas" daquela imagem construída pelo governo de Juan Domingo Perón. Pensamos ser possível analisar as memórias sobre Evita como "lugares de memória", nos quais uma determinada memória - existente ou pretendida - se entrelaça com a (re)elaboração de experiências vividas em um determinado presente, dotando este "lugar" de historicidade:

\footnotetext{
${ }^{8}$ Os especialistas debatem sobre o país de nascimento de Gardel, oscilando entre a França e o Uruguai. De qualquer maneira, Gardel veio muito criança para a Argentina, onde se estabeleceu.
} 
O que os constitui [os lugares de memória] é um jogo de memória e da história, uma interação dos dois fatores que leva a sua sobredeterminação recíproca. Inicialmente, é preciso ter vontade de memória. (...).

Em contrapartida, está claro que, se a história, o tempo, a mudança não interviessem, seria necessário se contentar com um simples histórico dos memoriais. Lugares, portanto, mas lugares mixtos [sic], híbridos e mutantes, intimamente enlaçados de vida e de morte, de tempo e de eternidade; numa espiral do coletivo e do individual, do prosaico e do sagrado, do imóvel e do móvel. ${ }^{9}$

Começaremos pela construção da "lenda negra", da imagem negativa sobre Evita, tendo como base a biografia The women with the whip - "A mulher com o chicote", em uma tradução literal -, de Mary Main, publicada nos Estados Unidos em 1952, logo após o falecimento da primeira-dama. Na Argentina, a biografia foi publicada em dezembro de 1955, dois meses depois do golpe de Estado que derrubou Perón e representou um instrumento de propaganda dos antiperonistas para legitimar o golpe dado contra o ex-presidente. Já nas décadas de 1960 e 1970, à "lenda negra" foi contraposta a imagem de uma Evita revolucionária, o que analisaremos a partir de Eva Perón iaventurera o militante?, livro do escritor Juan José Sebreli publicado originalmente em 1966. As imagens negativas e positivas sobre Eva Perón são bem conhecidas, mas o mesmo não se pode dizer dos textos de Mary Main e de Juan José Sebreli, sobretudo fora da Argentina, apesar de terem tido um papel fundamental na (re)elaboração do(s) mito(s) em torno da primeira-dama. Para termos uma ideia da repercussão do livro de Mary Main, aqui analisamos a quinta edição, que foi publicada já em 1956: segundo José Pablo Feinmann, as cinco edições alcançaram vinte e seis mil exemplares. Além disso, o livro inspirou o musical da Broadway sobre Evita. ${ }^{10}$ O livro de Sebreli não teve a mesma repercussão internacional, mas é representativo que tenha sido lançado em 1966, justamente o ano do golpe liderado pelo general Juan Carlos Onganía. Resumidamente, o golpe foi dado contra a legalização parcial do peronismo durante o governo de Arturo Illia (1963-1966), da União Cívica Radical do Povo (UCRP). O peronismo tinha sido colocado na ilegalidade depois do golpe de 1955 que derrubou Perón. O acentuado antiperonismo

\footnotetext{
9 NORA, Pierre. Entre memória e história: a problemática dos lugares. Projeto História, São Paulo, no 10, dez. 1993, p. 22.

${ }^{10}$ Cf. FEINMANN, José Pablo. Los libros de la Libertadora. Página/12, Buenos Aires, 04/05/2008. Disponível em: <http://www.pagina12.com.ar/especiales/archivo/peronismo_feinmann/ CLASE24.pdf $>$. Acesso em: 23 out. 2013.
} 
de Onganía estimulou a "radicalização" dos setores peronistas de esquerda que se formaram depois de 1955, o que resultou na formação de grupos armados como os Montoneros. E os setores de esquerda assumiram Evita como a face mais popular, nacional/nacionalista e revolucionária do peronismo. Além disso, vale lembrar, eram anos de Guerra Fria e de Revolução Cubana.

Em seguida, enfocaremos a memória contemporânea de Evita desde a (re)democratização do país no início da década de 1980, passando pela crise econômica e crescente reivindicação de Eva Perón por diferentes sujeitos e grupos político-sociais. Essa reivindicação tem feito a primeira-dama passar gradualmente de um ícone político-partidário, peronista, para um símbolo nacional, provocando um redirecionamento do seu significado político. Finalmente, contrapomos o(s) mito(s) à personagem histórica, destacando a necessidade de se inserir Eva Perón nas tensões culturais, econômicas, políticas e sociais de sua época. Essas tensões perpassaram a primeira-dama. Os discursos e livros atribuídos a Evita ainda são pouco estudados, são predominantemente lidos como mera propaganda política. Sem desconsiderar a pertinência dessa leitura, os discursos e os livros atribuídos a Evita são imprescindíveis para se compreender as tensões enfrentadas pela primeira-dama e, mais amplamente, pelo governo de Perón, inclusive por sua própria base social, como indica a segunda epígrafe que abre o artigo, na qual Evita se refere a uma greve. De um modo geral, trabalhos como Multidões em cena, de Maria Helena Rolim Capelato e Mañana es san Perón, de Mariano Plotkin, ainda analisam Evita a partir da imagem oficial divulgada pela propaganda peronista, como se esta propaganda mostrasse como foram as relações dos trabalhadores com Perón e Evita. Além disso, analisam esta imagem oficial como sinônimo da memória peronista. Em graus variados, a memória sobre Evita, desde então, apresenta rupturas com a imagem difundida pela propaganda peronista.

Como destaca a antropóloga Julie Taylor em Evita Perón: los mitos de una mujer, é inegável a interferência da propaganda peronista sobre os trabalhadores e a memória do período. Entretanto, é necessário considerar que existem sujeitos e grupos diferentes envolvidos no processo, que deram - e dão - sentidos particulares à imagem da primeira-dama. Segundo Taylor, a "(...) cultura de los propagandistas profesionales y los periodistas generalmente no es la del sector al que otros grupos de la Argentina atribuyen la creación del mito místico de Eva Perón: los estratos socioeconómicos inferiores de la sociedad". ${ }^{11}$ Consideramos que

\footnotetext{
${ }^{11}$ TAYLOR, Julie M. Evita Perón: los mitos de una mujer. Buenos Aires: Editorial de Belgrano, 1981, p. 14 [grifo meu].
} 
os próprios historiadores e demais especialistas no tema também poderiam ser colocados na mesma condição dos "propagandistas" e jornalistas.

\title{
A "lenda negra"
}

A "lenda negra" sobre Evita começou a ser construída antes de sua morte em 1952. Circulava, então, de forma "clandestina". Entretanto, após o seu falecimento e, principalmente, depois da queda de Perón em 1955, o processo se intensificou, pois os antiperonistas encontraram a oportunidade de transformar a "lenda negra" em uma imagem "oficial". A citada biografia de Evita escrita por Mary Main é representativa desse processo.

Mary Main era filha de ingleses, mas nasceu em Buenos Aires, pois o seu pai pertencia ao alto escalão da empresa ferroviária Buenos Aires Western Railway. Em 1941, se mudou com o marido para os Estados Unidos onde, anos depois, recebeu o convite para escrever a biografia da primeira-dama argentina. No início da década de 1950, foi para a Argentina recolher materiais para o livro e, temendo represálias, publicou a biografia nos Estados Unidos sob o pseudônimo de María Flores.

Em 1943, houve um golpe de Estado na Argentina, liderado por militares autoritários e anticomunistas, simpatizantes do Eixo na Segunda Guerra Mundial (1939-1945). Perón era general e foi um dos militares que lideraram o golpe. Nos Estados Unidos, a ditadura instaurada em 1943 na Argentina era associada ao nazi-fascismo. Essa visão permaneceu quando Perón foi eleito em 1946. A associação entre o peronismo e o nazi-fascismo está bastante presente no livro de Mary Main, um dos motivos pelos quais temia sofrer represálias:

\begin{abstract}
A pesar de la insistencia con que Perón afirma que el peronismo es una doctrina original, en realidad no consiste en otra cosa que en un fascismo modificado a fin de adaptarse a las circunstancias y modalidad de los pueblos de Sud América. (....). Los trabajadores, explotados durante tanto tiempo y muy simples en su inmensa mayoría, necesitaban desesperadamente algunos beneficios (...), de manera que no se dieron cuenta que estaban canjeando su independencia por un aguinaldo y llevados por el entusiasmo no se opusieron a reemplazar sus antiguos dirigentes por los candidatos de Perón. (...)

El gran público sólo veía su amable sonrisa y sólo escuchaba sus promesas. Todas las estaciones radiales que aventuraron una crítica terminaron perdiendo sus permisos - en esto pudo contar con la colaboración de Eva $-y$ los diarios opositores corrían en todo momento el riesgo de la clausura. ${ }^{12}$
\end{abstract}

\footnotetext{
${ }_{12}$ MAIN, Mary, op. cit., p. 50-51. O aguinaldo corresponde ao décimo terceiro salário dos argentinos.
} 
Assim, Eva Perón é destacada como um dos instrumentos peronistas destinados a reprimir os opositores e manipular os setores populares através das medidas sociais e trabalhistas, do carisma/demagogia e da censura. Conforme indica Federico Neiburg, a ideia da manipulação dos setores populares pelo peronismo foi recorrente, sobretudo nos primeiros anos depois do golpe de Estado que derrubou Perón em 1955 e ajudou a legitimar as ações dos antiperonistas. ${ }^{13}$ Ao associar Evita ao autoritarismo e à manipulação, a autora dissocia a primeira-dama das imagens de "santa", de "mãe dos descamisados" ou, ainda, de "ponte" entre os setores populares e Perón, como costumava ser definido o seu papel no governo devido à sua origem popular. Essa dissociação também é feita a partir da biografia de Evita.

Sobre a infância da primeira-dama, a autora aponta que a família passou por problemas econômicos, mas minimiza as dificuldades, "(...) ya que en esos días se podía obtener un kilo de carne por unos centavos". ${ }^{14}$ Além disso, Main destaca que os relacionamentos amorosos da mãe de Evita contornavam os problemas econômicos familiares. “(...) como sabía agradar a los hombres y quien es inteligente e inescrupulosa logra manejarlos, consiguió entusiasmar a un italiano (...)".15 Ao minimizar a pobreza enfrentada pela família de Eva Perón, a autora abala a imagem da origem popular da primeira-dama e, consequentemente, o papel de interlocutora dos setores populares que teria exercido junto ao presidente.

Por falar nos relacionamentos amorosos da mãe de Evita, a biografia se refere a um dos principais tabus da época, o fato da primeira-dama ser fruto de um relacionamento extraconjugal de seu pai, situação que provocava um forte rechaço moral. De acordo com Main, Eva Perón herdou da mãe a relação utilitária com os homens, como demonstraria sua ida para Buenos Aires, ainda muito jovem, com um cantor de tangos. "No tenía todavía dieciséis años cuando se escapó a Buenos Aires con él, abandonando a su madre sin mayor pesar". ${ }^{16}$ Os trabalhos artísticos que a jovem Eva teve nos primeiros anos em Buenos Aires e a condição de primeira-dama teriam sido obtidos da mesma forma. É sobretudo nesse aspecto que a autora dessacraliza Eva Perón.

No livro, a infância e a adolescência de Evita apresentam outros elementos que ajudariam a compreender como se formou a "mulher do chicote", "intolerante" com os que a cercavam e, principalmente, com os adver-

\footnotetext{
${ }^{13}$ NEIBURG, Federico. Os intelectuais e a invenção do peronismo. São Paulo: Edusp, 1997.

${ }^{14}$ MAIN, Mary, op. cit., p. 17.

15 Ibidem, p. 16.

16 Ibidem, p. 21.
} 
sários. A respeito da casa materna, a autora menciona que "(...) era bastante ruidosa pues doña Juana gritaba agudamente a sus hijos y ni ella ni su prole aprendieron nunca a controlar su temperamento". ${ }^{17}$ Quanto à formação intelectual, Main destaca que a jovem Eva Perón não possuía “(...) grandes aptitudes en el estudio (...)".18 A questão é retomada pela autora quando se refere a um episódio vivido por Evita como primeira-dama:

Todo el hemisfério occidental conoce su respuesta al periodista que la interrogó sobre sus autores favoritos - la nota se publicó en la revista Time - "Plutarco", respondió, "un escritor antiguo, como usted sabe". (...). No posé́a bastante seguridad en sí misma como para admitir lagunas en su educación (...). ${ }^{19}$

Ao apontar "problemas morais", dificuldade de convívio social e a formação intelectual lacunar, a autora apresenta Evita a partir de uma imagem invertida daquela esperada de uma mulher de elite no período. A autora reconhece a hostilidade da elite em relação a Evita, em virtude de sua origem popular e familiar "imprópria", mas considera que o sentimento era recíproco. Ao contrário do que tradicionalmente acontecia quando Perón foi eleito em 1946, as senhoras da elite portenha não entregaram à primeira-dama o posto de presidente da Sociedade de Beneficência, uma entidade de assistência social. Segundo Main, a resposta da primeira-dama veio em 1948 com a criação da Fundação Eva Perón, cujo objetivo seria ofuscar a Sociedade de Beneficência. "(...) su interés por la ayuda social se vinculaba, por mucho que pudiera existir una verdadera identificación con los pobres y desamparados, a su resentimiento contra la sociedad porteña". ${ }^{20}$

Assim, a "lenda negra" sobre Evita foi construída a partir de imagens opostas às difundidas pela propaganda peronista. À imagem da "justiça social" promovida pela primeira-dama foi contraposta a da "ressentida social", movida por interesses particulares e por sentimentos de revanchismo contra a elite que a hostilizava. À imagem da "santa" foi contraposta a da mulher "carnal", envolvida em diversos relacionamentos amorosos desprovidos de "amor" e de "princípios familiares". Apesar dessas diferenças, como bem assinala Julie Taylor, ambas as imagens tomam como parâmetro um mesmo ideal de feminilidade. Evita confirmaria este ideal na propaganda peronista e o negaria para os antiperonistas. "La Dama de la Esperanza y la mujer del Mito

\footnotetext{
17 Ibidem, p. 17.

18 Ibidem, p. 19.

19 Ibidem, p. 79.

${ }^{20}$ Ibidem, p. 80.
} 
Negro hacen afirmaciones positivas y negativas del mismo ideal femenino". ${ }^{21}$ Ainda segundo a autora, que fez pesquisa na Argentina no início da década de 1970, ambas as imagens ecoavam apenas de forma expressiva entre as classes altas e médias, pois, entre os trabalhadores, predominaria a presença de uma "(...) Eva realista y a veces revolucionaria (...)".22

\section{Evita "revolucionária"}

A relação com a esquerda é um ponto que ajuda a explicar a permanência de Eva Perón no cenário político-cultural argentino. Até o golpe de 1955, a esquerda argentina era predominantemente antiperonista, pois Perón era contra o comunismo e tinha pertencido à ditadura de 1943, conforme dissemos, simpatizante do nazi-fascismo. De um modo geral, a esquerda inclusive apoiou o golpe que derrubou Perón. Entretanto, após o golpe de 1955, Perón se exilou e parte expressiva da esquerda mudou de opinião, pois, com as medidas sociais e trabalhistas, o peronismo teria dado aos trabalhadores a noção de direitos e contribuído para mobilizá-los politicamente. A partir da década de 1960, Evita, Perón e Che Guevara passaram a dividir espaço em cartazes, faixas e panfletos de esquerda. Palavras de ordem como "Evita, Perón, revolução!" ou "Perón, Evita, a pátria socialista!" demonstravam a aproximação entre setores da esquerda e o peronismo.

O livro Eva Perón iaventurera o militante?, do escritor Juan José Sebreli, permite apreender esse movimento. O livro foi publicado originalmente em 1966. Porém, analisaremos a quarta edição, de 1971, ampliada pelo autor. Sebreli foi um dos jovens escritores de esquerda da revista Contorno (1953-1959) que, influenciados por Jean-Paul Sartre (1905-1980), se notabilizaram pela defesa de uma arte engajada. Não é casual a dedicatória do livro de Sebreli a Simone de Beauvoir (1908-1986), companheira de Sartre. Os jovens da Contorno tenderam a valorizar não propriamente o peronismo enquanto partido ou governo, mas as suas repercussões na sociedade argentina.

É claro o contraponto com o visto na biografia de Evita escrita por Mary Main. Main é inclusive citada por Sebreli. O escritor discorda de ver o peronismo como uma variação do nazi-fascismo, pois sua base social não

\footnotetext{
${ }^{21}$ TAYLOR, Julie M., op. cit., p. 229.

${ }^{22}$ Ibidem, p. 21. A "Eva realista" estaria relacionada aos "benefícios concretos" conquistados pelos trabalhadores graças à primeira-dama. Além disso, de acordo com Taylor, o reconhecimento dos sacrifícios feitos por Evita não necessariamente assumia um contorno religioso para os trabalhadores.
} 
seria a classe média. Para o escritor, uma variação do nazi-fascismo não teria sentido em um país “(...) con una clase obrera débil y sin perspectivas revolucionarias inmediatas". ${ }^{23}$ Apesar dessa falta de "perspectivas revolucionárias imediatas", Sebreli parece relacionar o peronismo a um questionamento da ordem e da hierarquia, o que também o afastaria do nazi-fascismo. "(...) el fascismo se caracteriza por su espíritu de seriedad, por la sacralización del Orden y la Jerarquía (...)".24 Sobre a infância e adolescência, o escritor ressalta que a mãe de Evita tinha uma pensão e não um prostíbulo como muitos defendiam. Sebreli destaca que a "imoralidade" atribuída à primeira-dama - como observamos em Main - pretendia prejudicar sua relação com os setores populares. Entretanto, o escritor não se pauta exatamente por uma "defesa moral" de Eva Perón. Pelo contrário, Sebreli lê positivamente as imagens da prostituta e da amante como sinais de questionamento à sociedade burguesa. A “(...) evasión de la rutina cotidiana por el amor es una forma rudimentaria de la subversión social". ${ }^{25}$

O escritor faz uma leitura semelhante em relação aos tempos de atriz de Evita. O desejo de ser atriz é relacionado a uma vontade de "viver outra vida", o que, de acordo com Sebreli, transgredia as limitações intelectuais e profissionais que eram então impostas às mulheres das classes médias e populares. Segundo Sebreli, as atrizes também provocaram uma mudança expressiva quanto às mulheres que eram referências para os setores populares. "La dama de la alta sociedad es reemplazada (...) por la 'estrella' (...) para las clases inferiores". ${ }^{26}$ Sebreli ainda destaca a militância de Eva Perón na organização sindical dos artistas, o que teria rompido antigos privilégios: "(...) en sus últimos años de actriz se ocupará más de cuestiones gremiales (...), chocando con los actores de viejo estilo que ponían su orgullo de estar por encima de los trabajadores asalariados". ${ }^{27}$

A respeito da condição econômica da família de Evita, o escritor, ao contrário de Main, reforça a origem popular da primeira-dama e defende que “(...) Eva Duarte [nome de solteira] conoce desde la infancia, el drama humano de la lucha de clases (...)"..28 Evita teria experimentado esse drama no velório do seu pai, quando teria sido hostilizada pela família "oficial".

Quanto à formação intelectual de Eva Perón, como mencionamos acima, Sebreli destaca as limitações que eram impostas às mulheres das classes

\footnotetext{
23 SEBRELI, Juan José, op. cit., p. 91[grifo meu].

${ }^{24}$ Ibidem, p. 91.

${ }^{25}$ Ibidem, p. 45.

${ }^{26}$ Ibidem, p. 41.

${ }^{27}$ Ibidem, p. 43.

${ }^{28}$ Ibidem, p. 22.
} 
pobres. "La condición social femenina no favorecía de ningún modo la actividad intelectual de la mujer de la clase media o de las clases populares". ${ }^{29}$ Apesar de destacar essa limitação que era imposta às mulheres, o escritor, em algumas passagens, ironiza o poder e a importância da cultura letrada. "¿Cómo se explica que 'esa pobre infeliz semianalfabeta' [Evita] haya podido arrastrar detrás de sí grandes masas populares, si no es mediante una diabólica genialidad?". ${ }^{30}$ Apesar disso, Sebreli não rompe totalmente com a cultura letrada enquanto elemento de legitimidade política e destaca de forma positiva a simpatia da primeira-dama por Plutarco, o que é ridicularizado na biografia escrita por Mary Main:

Claro está que ella misma no alcanzó a explicarse nunca lúcidamente las condiciones sociales de su vida. Su autoexplicación, derivada de las Vidas paralelas de Plutarco del que era lectora como Perón, es la concepción heroica de la historia, el voluntarismo idealista de las leyendas de los pueblos primitivos, de los estoicos, de los románticos, de Carlyle y su "culto a los héroes", de Emerson y Nietzsche, según la cual una personalidad excepcional, una voluntad inquebrantable moviéndose por sí misma puede modificar el curso de los acontecimentos. ${ }^{31}$

É interessante como Sebreli não refuta somente a "lenda negra", mas também a imagem de Evita difundida pela propaganda peronista. O escritor estabelece uma divisão entre a direção peronista e os trabalhadores. O "evitismo", formado por aqueles que, segundo Sebreli, seguiam o pensamento de Evita, seria a "ala plebeia do peronismo", composta principalmente pelos trabalhadores. Mais do que apontar as diferenças internas do peronismo, o escritor destaca as disputas entre os peronistas. Sebreli considera que o "evitismo" tinha sido derrotado pela burocracia, pela direção peronista. O falecimento de Eva Perón teria contribuído para a derrota dos trabalhadores. Assim, para Sebreli, Evita não devia ser vista como um aparelho do Estado, como notamos em Mary Main. "Tampoco es admisible (...) una variante (...) que muestra a Eva Perón como un mero producto mecánico de la máquina de Estado (...)".32

O escritor também critica a imagem oficial de Evita a partir da questão moral. Sebreli considera que os peronistas eram moralistas, assim como os antiperonistas, pois impuseram a Evita uma imagem estereotipada de santa e de esposa fiel, de acordo com os valores burgueses. "La historia profana de Eva Duarte que transcurre en un tiempo continuo, se convierte de pronto en historia sagrada que se

\footnotetext{
${ }^{29}$ Ibidem, p. 39.

30 Ibidem, p. 15.

31 Ibidem, p. 12.

32 Ibidem, p. 17.
} 
desarrolla en un tiempo eterno, $y$ desde entonces, la vida anterior, el pasado, se vuelve tabú". ${ }^{33}$ Em sua opinião, esse processo fez Evita ter uma "atitude passiva e contemplativa" diante de Perón. Mas caberia fazer uma distinção entre a "senhora Eva Perón", a primeira-dama, e a "companheira Evita", representativa do evitismo. Assim, Sebreli retoma uma distinção que era feita pela própria Eva Perón.

Apesar de Sebreli criticar a imagem difundida pela propaganda peronista e de se propor a resgatar a Eva Perón "profana", histórica, seu livro exerce um papel fundamental na construção de uma variante do mito, pois indica processos de apropriação da figura da primeira-dama. “(...) persiguiendo sus propios y egoístas fines personales, [Evita] contribuyó sin quererlo a la lucha por la emancipación parcial de la mujer y de la clase obrera de su país". 34 Além disso, vemos no autor uma variante do mito, pois realiza um "desenraizamento histórico" de Eva Perón ao colocá-la para além da história argentina. Conforme destacado na epígrafe, Evita é inserida por Sebreli na luta de libertação anti-imperialista da América Latina.

Apesar das mudanças na memória de Eva Perón que vemos no livro de Sebreli, Julie Taylor aponta que há permanências do modelo ideal de feminilidade na Evita "revolucionária". "(...) en parte o por completo, la Eva revolucionaria deriva de valores de la clase media, a pesar de las apariencias en el sentido contrario". ${ }^{55}$ Sebreli valoriza a "prostituta" e a "amante", mas se preocupa em desmentir que a mãe de Evita teria tido um prostíbulo. Ironiza e minimiza a importância da cultura letrada, mas se preocupa em apresentar Evita como uma autêntica leitora de Plutarco. O autor considera que o discurso moral em torno de Evita visava garantir - ou destruir - sua imagem entre os setores populares. Para Taylor, o "moralismo" é uma característica que as classes médias e altas atribuem aos setores populares, o que não é rompido efetivamente por Sebreli. Através da Evita "revolucionária", os intelectuais de esquerda pretendiam superar os antagonismos de classe que possuíam com os setores populares, dos quais desejavam se aproximar.

Os militares que derrubaram Perón iniciaram um processo de "desperonização" do país. Conforme destacamos, Perón seguiu para o exílio e o peronismo foi proibido e caiu na clandestinidade. Em 1955, os militares sequestraram o corpo de Evita, pois era um símbolo muito forte do governo anterior e crescia a santificação popular em torno de seu nome. O corpo foi

\footnotetext{
33 Ibidem, p. 53.

34 Ibidem, p. 76 [grifo meu].

35 TAYLOR, Julie, op. cit., p. 23.
} 
enterrado com um nome falso na Itália e seu paradeiro foi desconhecido por quinze anos. O local somente foi conhecido em 1970, quando os Montoneros sequestraram e mataram o general Pedro Eugenio Aramburu (1903-1970), um dos responsáveis pelo desaparecimento do corpo. Os militares devolveram o corpo de Evita para Perón, exilado em Madri. Consolida-se e difundese a associação do nome de Evita com a esquerda revolucionária.

Perón estava exilado e não tinha nada a perder com os novos seguidores de esquerda, aos quais incentivava a militarem no peronismo. Diante da sobrevivência política de Perón, os militares começaram um processo de abertura e legalização do peronismo. Em 1971, Perón nomeou Héctor José Cámpora (1909-1980) para ser o seu principal representante na Argentina. Cámpora era ligado aos grupos de esquerda que tinham aderido ao peronismo e comandou as negociações com os militares para legalizar o partido. Os militares aceitaram convocar eleições e permitiram que o peronismo participasse, desde que Perón não fosse candidato.

Cámpora foi o candidato peronista e foi eleito presidente em 1973. Cámpora organizou a volta de Perón. Quando Perón oficializou o desejo de voltar à presidência, Cámpora renunciou e convocou eleições, o que já era esperado desde o início das negociações para legalizar o peronismo. No mesmo ano, Perón foi eleito e assumiu a presidência.

Se por um lado essa aproximação da esquerda ajudou o peronismo a ganhar adeptos, por outro desencadeou disputas internas violentas no partido entre os setores à direita e à esquerda. Perón tentou controlar e desmobilizar a esquerda peronista quando voltou ao poder. Quando morreu em 1974, sua esposa Isabelita Perón era vice-presidente e assumiu o governo. Isabelita manteve a posição de Perón e, inclusive, autorizou os militares a reprimirem violentamente os grupos de esquerda do próprio partido. A cisão no partido aumentou com a morte de Perón e a consequente disputa por sua herança política.

Isabelita Perón tentou se apropriar da memória de Evita, então reivindicada principalmente pelos grupos de esquerda do partido. Ela organizou a volta do corpo de Evita da Espanha para a Argentina. O corpo foi colocado ao lado do de Perón em uma capela da residência presidencial de Olivos.

Os militares utilizaram as disputas internas do peronismo como pretexto para o golpe de março de 1976. Em outubro do mesmo ano, os militares organizaram o sepultamento do corpo de Eva Perón no jazigo de sua família no cemitério da Recoleta, onde permanece. Evita foi sepultada com proteção especial para evitar novos usos políticos do corpo. De qualquer maneira, o nome de Evita continuou a circular clandestinamente entre os peronistas, sobretudo na linha de frente contra a ditadura. 


\section{A memória de Eva Perón na Argentina contemporânea}

A ditadura durou até 1983, marcada por trinta mil desaparecidos políticos, crise econômica e uma guerra, a das Malvinas (1982), que vitimou centenas de jovens soldados. Apesar desse quadro, os peronistas perderam as eleições presidenciais de 1983, vencidas por Raúl Alfonsín da União Cívica Radical (UCR). Dentre as causas da derrota podem ser apontadas as divisões internas do peronismo que, naqueles anos, estiveram profundamente relacionadas aos métodos de luta que tinham sido empregados contra a ditadura: parte dos peronistas discordava das ações armadas que tinham sido adotadas por outra parte representada, sobretudo, pela guerrilha dos Montoneros. Essas divisões, somadas à repressão dos militares durante a ditadura, dificultaram a rearticulação dos peronistas para as eleições. Além disso, setores expressivos da sociedade argentina temiam que a eleição dos peronistas mantivesse a instabilidade e o "radicalismo" político daqueles anos.

Naquele imediato pós-ditadura, o governo Alfonsín foi marcado pela tentativa de conciliar os diferentes grupos político-sociais. Por um lado, não houve nenhuma reivindicação efetiva da memória de Eva Perón, pois não era um governo peronista e a primeira-dama ainda era fortemente associada ao "radicalismo" peronista. Mas tampouco ocorreu o inverso: a necessidade de cortejar os peronistas fez com que o governo Alfonsín não se pautasse por ações contra a memória da primeira-dama e de outros expoentes do peronismo.

O governo do presidente peronista Carlos Menem (1989-1999) foi marcado por políticas neoliberais. Assim, ele rompeu com o modelo de Estado consolidado por Perón. Entretanto, Menem procurava legitimar seu governo nos pressupostos peronistas e defendia que era preciso adaptá-los às mudanças ocorridas desdePerón. Em 1996, no prólogo de uma reedição de Doctrina peronista, escrito por Perón, Menem manifestou sua "lealdade" aos princípios peronistas:

El Movimiento Nacional Peronista enfrenta en la actualidad el momento más álgido de sus casi 40 años de existencia (...). Volver a las fuentes de donde emana la Doctrina Nacional es una premisa insoslayable. Quienes integramos la falange de mujeres y hombres que asumimos en plenitud total los postulados del Peronismo ratificamos nuestra condición de misioneros de una causa irrenunciable. ${ }^{36}$

\footnotetext{
${ }^{36}$ MENEM, Carlos Saúl. Prólogo. In: PERÓN, Juan Domingo. Doctrina peronista. Buenos Aires: C. S. Ediciones, 1996, p. 13.
} 
Javier Burdman considera que a derrota do peronismo nas eleições presidenciais de 1983 abriu o caminho para a releitura dos pressupostos peronistas empreendida por Menem. O autor desenvolve alguns exemplos, como o da justiça social. Burdman lembra que, em Perón, o princípio remetia à necessidade de se lutar contra as desigualdades "de classe" existentes entre os "descamisados" e a "oligarquia". Já nos discursos de Menem, o autor destaca que a justiça social também é recorrente, porém, sob a perspectiva neoliberal, “(...) no se constituye en oposición a la explotación y la oligarquia, sino al privilegio, expresado (...) en las prebendas estatales, la burocracia, la especulación y la falta de competencia" ${ }^{37}$

Contudo, com o avanço da crise econômica, muitos peronistas romperam com o governo e se intensificou uma disputa simbólica - e política - em torno da memória de Perón e, sobretudo, de Evita. Representativa dessa disputa foi a repercussão negativa desencadeada pela gravação de cenas do filme de Alan Parker na Casa Rosada. A permissão dada pelo governo desagradou a setores do peronismo. Foi interpretada como um sinal de subserviência de Menem frente a "representantes do imperialismo norte-americano". Teria demonstrado, ainda, sua indiferença frente ao descontentamento gerado pela escolha de Madonna para interpretar Evita. Uma reportagem do jornal Clarín sobre a pré-estreia do filme na Argentina indica aspectos dessa disputa:

(...) aparecieron grupos militantes - menos de cincuenta - del peronismo portando pancartas. "Viva Evita, fuera Madonna", decían los carteles. Los firmaba el Comando de Organización.

Entre quienes protestaban pudo verse al peronista histórico Alberto Brito Lima, líder de la agrupación. "Esta película no es una obra de arte sino una agresión psicológica al pueblo argentino", dijo Brito Lima a Clarín.

La Confederación General del Trabajo (CGT), en un comunicado también había expresado que "la abanderada de los humildes resulta una vez más agraviada, esta vez en forma de película (...)".38

Apesar de o jornal minimizar o número de manifestantes - "menos de cinquenta" -, o agravamento da crise econômica, a repercussão negativa do filme no país e as crescentes críticas que recebia, inclusive de seu próprio partido, fizeram Menem intensificar a construção da imagem de continua-

\footnotetext{
${ }^{37}$ BURDMAN, Javier. La rearticulación identitaria del peronismo a partir del discurso de Carlos Menem. Una perspectiva desde los enfoques de Ernesto Laclau y Slavoj Zizek. Memoria y sociedad, Bogotá, n²5, v. 12, jul.-dez. 2008, p. 12. Disponível em: <http://memoriaysociedad.javeriana. edu.co/anexo/articulo/doc/d42_25_1.pdf>. Acesso em: 28/04/2012.

${ }^{38}$ Estreno con ruido de la "Evita" de Madonna y Parker. Clarín, Buenos Aires, 18/02/1997. Disponível em:<http://edant.clarin.com/diario/1997/02/18/e-03001d.htm>. Acesso em: 28/04/2012.
} 
dor de Perón e Evita. No que se refere à Eva Perón, em 23 de setembro de 1998, seu governo decretou a criação, em Buenos Aires, do Instituto Nacional de Investigaciones Históricas Eva Perón - Museo Evita, com a finalidade de estimular pesquisas e de preservar a memória da primeira-dama.

Além disso, em 1999, dez dias antes de deixar o governo, Menem inaugurou na capital argentina um monumento dedicado a Eva Perón ao lado da Biblioteca Nacional do país. O presidente inaugurou a pedra fundamental do monumento em 23 de setembro de 1997, uma data carregada de simbolismo para o peronismo: 50 anos antes, Evita anunciou a promulgação da lei que concedeu o voto feminino, fruto de uma campanha protagonizada pela primeira-dama naqueles anos. Além disso, no local ficava a residência presidencial onde viveram Perón e Evita e na qual faleceu a primeira-dama. A residência foi demolida a mando dos militares que derrubaram Perón em 1955.

Apesar dessas tentativas de Menem, com o agravamento da crise econômica, cresceu a imagem do presidente como um traidor dos princípios peronistas. Os opositores contrapõem a Menem à imagem da Argentina peronista das décadas de 1940 e 1950, colocada como um "paraíso perdido", destruído pelas políticas neoliberais que, implantadas pela ditadura de 1976, teriam sido aprofundadas pelos governos liberal-democráticos, especialmente pelo de Menem.

A imagem de Eva Perón é fortemente associada a esse "paraíso perdido". A obra do pintor Daniel Santoro é um dos melhores exemplos dessa associação. Em um quadro, Eva Perón decapita al embajador S. B. (2002), Evita decapita Spruille Braden (1894-1978), o - antiperonista - embaixador dos Estados Unidos na Argentina quando Perón foi eleito presidente em 1946. Outra associação de Eva Perón com o anti-imperialismo é Evita castiga al niño gorila (1999). Na Argentina, gorila é uma forma de se referir pejorativamente aos que seriam porta-vozes do imperialismo. Eva Perón ainda aparece associada ao emprego, ao estudo e à aquisição de bens materiais em quadros como La felicidad del pueblo (2000). Evita como símbolo de um Estado protetor também aparece em Evita protege al niño peronista (2002). ${ }^{39}$ Assim Daniel Santoro se refere à sua obra:

Lo que intento con la figura de Eva Perón es una especie de arquetipo que sería como la madre Estado. (...). Sería una nueva categoría que creo que es un invento del peronismo (...). (...). (...) el viejo liberalismo, antes de que se pusiera salvaje (...), tenía un lado paternalista, y en general terminó siendo el padre de algunos pícaros empresarios y banqueros. Lo que hizo finalmente fue malcriar banqueros, que es lo

\footnotetext{
39 As obras citadas podem ser consultadas no site do pintor: $<$ http://www.danielsantoro.com.ar/ $>$.
} 
que estamos viviendo hoy en día. En cambio, el Estado maternal es ese Estado sensible que se hace a cargo realmente de los desamparados. Y restituye la justicia social. Eva Perón piensa en una república para los niños (...) que no tienen padres. Y piensa en cada una de las situaciones en las que el Estado debe hacerse presente. (...). ${ }^{40}$

Daniel Santoro tem uma trajetória ligada ao peronismo. No começo da década de 1970, quando estava na Escola Nacional de Belas Artes da Argentina, militava no peronismo. Entretanto, o que se nota em meio à crise são reivindicações de Eva Perón, semelhantes às de Santoro - e Sebreli -, "fora" do peronismo, como as feitas por movimentos piqueteros, compostos por desempregados, cujo número aumentou acentuadamente no país no decorrer da década de 1990. A base social clássica do peronismo é o trabalhador sindicalizado, tradição abalada, assim, pelos movimentos piqueteros, que se apropriam da memória peronista e, particularmente, de Evita. Os piqueteros surgem com uma profunda crítica às instituições, incluindo os partidos e sindicatos existentes. Em outras palavras, Evita aparece como um símbolo de movimentos sociais, além daqueles diretamente envolvidos com o peronismo em maior ou menor grau.

Fernando de la Rúa, da UCR, venceu as eleições presidenciais de 1999 com a proposta de abandonar as políticas empreendidas por Menem. O novo presidente se apresentava como um canalizador das aspirações dos movimentos populares. Em relação à memória de Eva Perón, como presidente não peronista que era, manteve uma posição protocolar, mas valorativa da memória da primeira-dama. No $48^{\circ}$ aniversário da morte de Evita, de la Rúa organizou uma missa em memória da primeira-dama em uma capela da residência presidencial. A missa contou com a participação de governadores, dentre os quais estavam muitos peronistas. ${ }^{41}$ Além disso, habilitou o imóvel para funcionar o Instituto Nacional de Investigaciones Históricas Eva Perón, criado por Menem. "En un comunicado, la Casa de Gobierno dijo que él presidente de los argentinos expresó el más respetuoso recuerdo a su memoria [de Evita]'".42 No entanto, de la Rúa não conseguiu romper com as políticas menemistas e o

\footnotetext{
${ }^{40}$ Apud ROSANO, Susana. El paraíso perdido del peronismo, en clave hermética (Algunos apuntes para pensar la obra de Daniel Santoro), p. 4. Disponível em: <http://www.unsam.edu.ar/ home/material/rosano.pdf>. Acesso em: 29/04/2012.

${ }^{41}$ Una misa que sorprendió a todos. Clarín, Buenos Aires, 27/07/2000. Disponível em: <http:// edant.clarin.com/diario/2000/07/27/p-00302.htm>. Acesso em: 14/05/2012.

${ }^{42}$ Un recuerdo. Clarín, Buenos Aires, 27/07/2000. Disponível em: <http://edant.clarin.com/diario/2000/07/27/p-00902.htm>. Acesso em: 14/05/2012.
} 
seu governo foi marcado pelo aprofundamento da crise. Fernando de la Rúa renunciou em 2001 em meio à grave crise econômica, política e social. Seguiram-se governos de transição, dentre os quais o mais representativo foi o do peronista Eduardo Duhalde (2002-2003), segundo colocado nas eleições de 1999. Duhalde começou um rompimento com o menemismo.

O peronista Néstor Kirchner assumiu a presidência em 2003 apresentando-se como uma ruptura com o peronismo de corte neoliberal representado por Carlos Menem. O presidente iniciou uma política de aproximação/ cooptação dos movimentos sociais, com destaque para os piqueteros. A recuperação econômica, o clientelismo e o peso da tradição peronista fizeram com que essa política de Kirchner em relação aos movimentos sociais fosse bem-sucedida. Para legitimar esse processo, Kirchner reivindicava a "Evita revolucionária". Apesar da recuperação da "Evita revolucionária" por um governo peronista, manifestações no $52^{\circ}$ aniversário de falecimento da primeira-dama demonstram como a memória de Eva Perón estava dividida entre diferentes sujeitos e grupos político-sociais:

El presidente Néstor Kirchner y su esposa (...) encabezaron el acto (...), en el que no hubo discursos políticos, sino expresiones artísticas (...).

(...). Contra lo que marca la liturgia peronista, el acto no culminó con la tradicional marcha, y el silencio fue aprovechado por las varias decenas de piqueteros de las agrupaciones kirchneristas (Federación Tierra y Vivienda, Barrios de Pie y MTD Evita) que participaron del acto. "Si Evita viviera, sería piquetera", cantaban (...).

(...).

Desde la oposición, (...) Elisa Carrió, recordó las figuras de Eva Perón y de Leandro N. Alem (...). También se hicieron eco del aniversario las agrupaciones de izquierda y piqueteras Patria o Muerte, Martín Fierro, Juventud de Fierro, el Movimiento Atahualpa y el Frente Barrial 19 de Diciembre con "un acto antiimperialista".43

Nas eleições presidenciais de 2007, a candidatura da então senadora e primeira-dama Cristina Kirchner estimulou comparações com a figura de Eva Perón. Outro elemento colaborou para estimular essas comparações e desencadear uma disputa em torno da memória de Evita: outra mulher, Elisa Carrió, aparecia como forte candidata pelo ARI (Afirmación para una República Igualitaria). Além da justiça social associada a Eva Perón, a questão da

\footnotetext{
${ }^{45}$ Dirigentes peronistas y opositores recordaron la figura de Eva Perón. La Nación, Buenos Aires, 27/07/2004 [grifos meus]. Disponível em: <http://www.lanacion.com.ar/622226-dirigentes-peronistas-y-opositores-recordaron-la-figura-de-eva-peron >. Acesso em: 14/05/2012. Leandro N. Alem foi fundador da UCR.
} 
igualdade de gênero ganhou importância na campanha e ambas colocavam as suas candidaturas como resultado da ação de Evita em defesa do voto feminino, apesar de Carrió não ser peronista. No início deste artigo, quando Carrió afirma que "Eva Perón foi uma rainha de verdade e não uma rainha do botox", refere-se indiretamente a Cristina e, além da animosidade da campanha, indica a disputa entre ambas pela figura de Evita. Em tempo, as duas tiveram as maiores votações, tendo Cristina vencido a eleição.

No governo de Cristina, a apropriação de Eva Perón pelo kirchnerismo foi aprofundada. Sob seu governo se evidencia um processo interessante em torno da "Evita revolucionária": o tradicional par Evita-Juan Domingo Perón parece perder espaço para pares como Evita-Che Guevara, Evita-Héctor Cámpora ou, ainda, Evita-Tupac Amaru, ${ }^{44}$ ressaltando a dimensão latino-americanista de sua memória, conforme apontado por Juan José Sebreli.

Fabián Bosoer destaca que Evita, assim como Cámpora, remetem a projetos "não cumpridos", não pelo fracasso dos projetos ou dos proponentes em executá-los, mas por conjunturas que impediram sua conclusão. Podemos pensar, no caso de Evita, na morte prematura. Quanto a Cámpora, a renúncia precoce em 1973, em favor da candidatura de Perón, colocou os setores de esquerda do peronismo à margem do movimento/partido, frustrando as expectativas de um processo revolucionário com o apoio do Estado argentino. Segundo Bosoer, a reivindicação que Cristina faz de Eva Perón e de Cámpora se sustenta pela ideia de concretizar o projeto de ambos:

(...) el matrimonio Kirchner podría cumplir con algunas asignaturas pendientes del peronismo: la primera, completar un mandato y un programa que el presidente peronista de izquierda que antecedió a Perón, Héctor Cámpora, no pudo llevar a cabo en 1973, ya que fue forzado a renunciar 40 días después de haber asumido para posibilitar el regreso al poder del líder máximo. La segunda asignatura es mostrar que una mujer está en condiciones de gobernar y liderar un proyecto político dentro de un movimiento $y$ de un país que comparte con el resto de la región una cultura fuertemente machista. ${ }^{45}$

A geração da década de 1970 está no poder na Argentina. Parte dessa geração tem uma relação um tanto dúbia com a figura de Perón. Apresentase como herdeira de seu discurso nacionalista e popular, mas foi combatida

\footnotetext{
${ }^{44}$ Tal associação pode ser vista no site da Organización Barrial Tupac Amaru: <http://www. tupacamaru.org.ar/>. Acesso em: 15/05/2012.

${ }^{45}$ BOSOER, Fabián. Kirchner, segundo acto: el panorama electoral en Argentina. Nueva Sociedad, ${ }^{\circ}$ 208, março-abril de 2007, p. 23. Disponível em:<http://www.nuso.org/upload/articulos/3414_1. pdf $>$. Acesso em: 29/04/2012.
} 
por Perón quando este retornou ao país em 1973. Por isso, sob os Kirchner, Héctor Cámpora e Evita têm sido recuperados como ícones "da esquerda" do partido, mais do que o próprio Perón. O filho de Néstor e Cristina, Máximo Kirchner, lidera uma agremiação peronista chamada La Cámpora, que controla postos centrais do governo.

Ainda no que se refere à questão de gênero, em 9 de março de 2009, portanto no dia seguinte ao Dia Internacional da Mulher daquele ano, a presidente Cristina Kirchner inaugurou uma nova sala na Casa Rosada, o Salón Mujeres Argentinas del Bicentenário, para homenagear as mulheres consideradas representativas da história do país. Foram escolhidas 12 mulheres, cada uma homenageada com um painel fotográfico. Evita, evidentemente, ocupa lugar de destaque e a presidente costuma discursar no local perto de sua imagem.

Às 20h25min de 26 de julho de 2011, portanto, no $59^{\circ}$ aniversário do falecimento de Eva Perón, Cristina Kirchner inaugurou um mural gigante com a imagem da primeira-dama na fachada do prédio onde funcionam os ministérios da Saúde e o do Desenvolvimento Social, em plena avenida 9 de Julho, uma das principais da capital argentina. O evento foi carregado de simbolismo, como demonstra o horário da inauguração. Evita morreu oficialmente às 20h25min e, durante o governo de Perón, o horário do seu falecimento era continuamente lembrado pelos meios de comunicação, sobretudo pelo rádio. Além disso, na avenida 9 de Julho, em 22 de agosto de 1951, ocorreu uma das principais concentrações populares da história do peronismo. A concentração pretendia consagrar Evita como candidata a vice-presidente de Perón nas eleições de 1952. Porém, dias depois, a primeira dama declinou da candidatura.

Outro dado importante é que o painel de Evita foi inspirado no de Ernesto Che Guevara existente na praça da Revolução em Havana, capital de Cuba. O painel de Evita remete, assim, ao "peronismo de esquerda" da década de 1970, do qual Cristina Kirchner se coloca como herdeira. Finalmente, o Ministério do Desenvolvimento Social, onde o painel de Evita foi fixado, é ocupado desde 2006 por Alicia Kirchner, irmã de Néstor e cunhada de Cristina. Alicia também ocupou o cargo entre 2003 e 2005. O ministério remete ao trabalho desempenhado por Eva Perón na fundação de assistência social que a primeira-dama criou em 1948.

O processo iniciado por Néstor Kirchner quanto à aproximação do governo em relação aos movimentos sociais, particularmente os piqueteros, foi aprofundado por Cristina, reeleita em primeiro turno em 2011. Mas setores da oposição continuaram - e continuam - reivindicando para si a memória de Eva Perón, conforme observamos na epígrafe, quando o cineasta Fernan- 
do Pino Solanas lembra a primeira-dama no $58^{\circ}$ aniversário de sua morte. O cineasta foi peronista na década de 1970, mas atualmente lidera o Proyecto Sur, movimento político de centro-esquerda. Foi candidato a presidente em 2007, o segundo deputado nacional mais votado pela cidade de Buenos Aires nas eleições de 2009 e, em 2010, foi candidato a chefe de governo da capital argentina, cargo semelhante ao de prefeito. A permanência de Cristina como porta-voz privilegiada do projeto peronista "de esquerda" e da memória de Evita dependerá das disputas internas que caracterizam o peronismo e, sobretudo, da saúde econômica do país.

\section{Considerações finais: Evita, entre o(s) mito(s) e a personagem histórica}

Em A paixão e a exceção, publicado em 2003, Beatriz Sarlo procura compreender como se deu a excepcionalidade de Eva Perón, do âmbito artístico para o político. Ao contrário do que tradicionalmente defendem os peronistas e os antiperonistas, a autora enxerga uma ruptura, um deslocamento entre a Eva atriz e a primeira-dama. Para os peronistas, a continuidade entre os dois âmbitos estaria na facilidade com a qual Evita se comunicava com os setores populares; para a oposição, na facilidade em enganá-los. Sarlo, contudo, ao analisar o visual como um elemento central do discurso peronista, aponta que a imagem da Eva atriz, sujeita ao caráter efêmero da moda, não poderia corresponder à da primeira-dama de um governo que pretendia ser eterno e universal. Os vestidos e as joias da primeira-dama não são vistos pela autora sob a perspectiva simplificadora do ressentimento social ou da ambição de Eva Perón; ${ }^{46}$ são considerados no livro como um assunto de Estado. A suntuosidade, o "exagero" das roupas e dos adornos, assim como a austeridade do tailleur - que também marcou seu guarda-roupa - estariam além do que era considerado bom gosto e, portanto, denotariam o caráter atemporal desejado pelo peronismo. “(...) não se trata meramente da mulher de um presidente (...); Eva está representando um novo regime político".47 Sarlo demonstra, assim, como a imagem de Eva Perón foi construída e serviu como instrumento de propaganda.

\footnotetext{
${ }^{46}$ Essa imagem está presente, por exemplo, na biografia escrita por Mary Main.

47 SARLO, Beatriz. A paixão e a exceção: Borges, Eva Perón, Montoneros. São Paulo: Companhia das Letras; Belo Horizonte: Editora UFMG, 2005. p. 97.
} 
Nora Domínguez aponta algo semelhante em relação ao coque. De acordo com a autora, para ressaltar o coque, se popularizou a imagem de perfil de Evita, o que também teria conferido atemporalidade à sua imagem. "Esa cabeza ya no es la de una mujer, sino un emblema: pierde la mirada frontal, solo puede mirar el pasado o el futuro". ${ }^{8}$

Contudo, Sarlo chama a atenção quando destaca as características físicas naturais de Eva Perón que teriam reforçado a atemporalidade buscada pelo peronismo. Sarlo cita, dentre outras, o "rosto arredondado", a "cintura de vespa", “(...) seu corpo sem curvas marcadas, cada vez mais delgado (...)". ${ }^{49}$ Então, a ruptura, o deslocamento entre a atriz e a primeira-dama teria sido, em parte, um reencontro consigo mesma? Ao naturalizar traços "atemporais" de Eva Perón, a autora estaria legitimando o mito formado em torno da primeira-dama? Sarlo tem consciência do perigo de ser interpretada dessa maneira.

Na excepcionalidade de Eva houve um "fora do lugar", uma passagem de qualidades que, justamente na passagem, potencializaram-se e tornaram-se adequadas, embora adequadas não seja a palavra exata, já que não se adequaram a nada que preexistisse, e sim criaram a situação para a qual seriam adequadas. ${ }^{50}$

No entanto, Sarlo não desenvolve o raciocínio. Problema semelhante quanto à "naturalização do mito" aparece em Multidões em cena, de Maria Helena Rolim Capelato. Segundo a autora, "Eva Perón configurou-se como personagem adequada para representar a encarnação viva do mito feminino da redenção. (...). (...) seus dotes físicos tornavam-na especialmente dotada para a representação da feminilidade ideal, expressão do bem, do bom e do belo". ${ }^{51}$ É claro que os traços físicos podem ser moldados como a vestimenta, as joias e o penteado, mas se trata de um elemento que tende a reforçar o mito, a naturalizar a excepcionalidade, ao invés de estimular uma reflexão sobre a construção de Evita e as apropriações de sua imagem.

Para se compreender a história e a memória de Evita é necessário priorizar a leitura do(s) mito(s) em torno da primeira-dama a partir de outro ponto. Não é o caso de se negar a biografia ímpar de Eva Perón, mas é preci-

\footnotetext{
${ }^{48}$ DOMÍNGUEZ, Nora. Los rostros de Eva Perón. In: SORIA, Claudia, ROCCA, Paola Cortés e DIELEKE, Edgardo (org.). Políticas del sentimiento: el peronismo y la construcción de la Argentina moderna. Buenos Aires: Prometeo Libros, 2010. p. 134.

49 SARLO, op. cit., p. 81.

${ }^{50}$ Ibidem, p. 24-25.

${ }^{51}$ CAPELATO, Maria Helena Rolim. Multidões em cena: propaganda política no varguismo e no peronismo. $2^{\mathrm{a}}$ ed. São Paulo: Editora Unesp, 2009, p. 297 [grifo meu].
} 
so não igualar o(s) mito(s) à personagem histórica, ainda que ambos estejam relacionados. Cabe ler menos o(s) mito(s) a partir da personagem histórica, como se fosse(m) derivado(s) da própria Evita e enfocar mais a personagem histórica a partir do(s) mito(s) construídos pelos sujeitos e grupos político-sociais em seus fins conscientemente procurados, para parafrasearmos Marc Bloch. ${ }^{52}$ Sejam esses fins o de Mary Main, o de Sebreli ou dos piqueteros. Tal papel ativo dos sujeitos e grupos não se deu apenas a posteriori, mas também foi contemporâneo à primeira-dama. Ao atribuirmos à personagem histórica a condição de mito, como Sarlo e Capelato - quase - fazem acima quando citam os traços físicos "atemporais" de Evita, desconsideramos as tensões políticas, sociais e culturais enfrentadas pela primeira-dama não somente com os antiperonistas, mas com a sua própria base social.

Vejamos alguns exemplos. No começo deste artigo, vimos como Eva Perón defendia o fanatismo pelo peronismo. Entretanto, essa defesa encontrou resistências na sociedade argentina:

(...) "el hombre mediocre es el más feroz y más frío enemigo del hombre de genio". Todo lo extraordinario es para ellos locura imperdonable, fanatismo exagerado y peligroso. Yo los he visto y los veo todavía mirándome "compasivos" $y$ "misericordiosos" con ese aire de superioridad que los define... Nunca entenderán cómo y por qué alguien puede hacer una cosa distinta de los que ellos piensan y nunca hacen nada que no sea para ellos. ${ }^{53}$

A necessidade de responder aos que viam fanatismo no peronismo indica que, em alguma medida, a associação do governo de Perón com o excessivo foi além dos círculos oposicionistas.

Apesar de se apresentar como antiliberal, é interessante notar como o temor dos setores populares também está presente no discurso peronista. É um discurso que se apresenta como representante dos setores populares, ponto de ruptura com a política então em voga, mas assim se apresenta justamente para conter estes setores. Sobre as necessidades populares, Evita dizia ser necessário atender todos os pedidos “(...) se não quisermos que o povo deixe de ver em Perón o seu condutor".54

Outro ponto a ser problematizado no discurso peronista é o nacionalismo. Frequentemente visto como um instrumento de manipulação dos seto-

\footnotetext{
52 "A história trata de seres capazes, por natureza, de fins conscientemente procurados." (BLOCH, Marc. Introdução à história. Lisboa: Publicações Europa-América, 1976, p. 124).

53 PERÓN, 1996, p. XXXIX.

${ }^{54}$ PERÓN, s/d, p. 142.
} 
res populares por mascarar as desigualdades de classe, o seu apelo recorrente deve ser pensado não necessariamente como um indicativo da ausência de tensões sociais, mas, pelo contrário, como uma tentativa, nem sempre bem-sucedida, de contê-las. Em Perón o muerte (1986), Eliseo Verón e Silvia Sigal acreditam que a permanência do nacionalismo no discurso peronista, inclusive durante a década de 1970, indica uma divergência entre o movimento/governo e o povo argentino, sendo que o apelo não teria tido o efeito esperado pelo peronismo. “(...) si esta identidad de principio [o nacionalismo] tiene todavía la forma de una exigencia, de un programa, es porque la coincidencia entre el movimiento y el pueblo argentino no se ha logrado todavía enteramente" ${ }^{55}$

No discurso peronista, o fanatismo está atrelado à lealdade. A lealdade deveria ser uma devoção voluntária e sincera à causa peronista. Sinceridade que deveria se manifestar como desprendimento pessoal, em um intento claro de coibir disputas internas que poderiam repercutir negativamente na orientação dos setores populares. "La lealtad para con la masa [e/ou com o governo, "representante" desta massa] engendra lealtad hacia el dirigente que la practica" ${ }^{56}$

Não se trata, apenas, de um recurso "demagógico": por trás da necessidade de se estimular a lealdade das lideranças políticas está o medo da "instabilidade" dos setores populares. Em meio ao delineamento da crise econômica e política no início da década de 1950, essa estratégia se torna mais evidente. Em 17 de outubro de 1951, Dia da Lealdade peronista, o último do qual participou, Evita pediu o seguinte à multidão reunida na praça de Maio. "(...) juremos todos, públicamente, defender a Perón y luchar por él hasta la muerte. Y nuestro juramento será gritar durante un minuto para que nuestro grito llegue hasta el último rincón del mundo: La vida por Perón". ${ }^{57}$

Cabe comparar esse pedido com a passagem da autobiografia $A$ razão de minha vida, também de 1951, na qual Evita se refere a uma greve, destacada na

\footnotetext{
${ }^{55}$ SIGAL, Silvia e VERÓN, Eliseo. Perón o muerte: los fundamentos discursivos del fenómeno peronista. Buenos Aires: Legasa, 1986, p. 61-62.

${ }^{56}$ PERÓN, 1996, p. LI.

${ }^{57}$ Eva Perón. Cuadernos de Crisis, Buenos Aires, nº 7, 1974, p. 45. Após a derrota do Eixo na Segunda Guerra Mundial, aumentaram as pressões internas e externas pelo fim da ditadura de 1943 e democratização do país. Perón, devido ao acúmulo de poderes - era vice-presidente, ministro da Guerra e secretário do Trabalho -, foi um dos principais alvos dos protestos organizados por setores liberal-democráticos e por trabalhadores comunistas e socialistas. Em 9 de outubro de 1945, Perón renunciou aos cargos. As pressões continuaram e, no dia 13, Perón foi preso pela ditadura. No entanto, a prisão desagradou aos trabalhadores simpatizantes de Perón e, no dia 17, milhares deles saíram às ruas de Buenos Aires para pedir a sua libertação. A ditadura cedeu, libertou Perón e convocou eleições, as quais venceu em fevereiro do ano seguinte.
} 
epígrafe. Sobre a mesma greve, a primeira-dama destacou que “(...) não posso imaginar que haja ainda na Argentina um só trabalhador que não tenha compreendido o que é Perón e tudo o que tem feito a bem dos trabalhadores" ${ }^{58}$

Como destacam Eliseo Verón e Silvia Sigal, no discurso peronista os adversários políticos são constantemente mencionados tendo em vista manter a mobilização da sua base social contra estes adversários. No entanto, o trecho acima não se enquadra nessa característica. Nenhum trabalhador era considerado adversário do governo. Em relação a setores da esquerda, as críticas de Perón e Evita recaíam sobre os líderes sindicais e não sobre os trabalhadores.

Assim, o trecho sobre a greve indica muito mais os limites do discurso peronista do que um apelo bem-sucedido para mobilizar sua base social, como reconhece a própria Eva Perón. "Estivesse este livro voltado para fins propagandistas e certamente não teria inserido nele estas páginas tristes".59 Nesses limites está um dos motivos pelos quais o discurso peronista, apesar do tom sectário, nunca ter se fechado totalmente, inclusive em relação aos seus tradicionais adversários. Se por um lado "todo trabalhador era um descamisado", Evita também defende, em A razão de minha vida, que "nem todo descamisado era um trabalhador", o que ampliava as possibilidades de composição da base social peronista.

Essas tensões não aparecem com destaque em trabalhos como Multidões em cena, de Capelato. O objetivo da autora é analisar a propaganda política, como indica o subtítulo do livro, propaganda política no varguismo e no peronismo. Porém, o texto faz referências a uma suposta recepção positiva dessa propaganda, inclusive no que se refere ao papel de Evita no peronismo. "A evocação do temor da fragmentação e dos conflitos, aliada à imagem da sociedade unida e harmônica, alardeada pela propaganda peronista, explica a receptividade do poder salvador e redentor [de Perón e Evita, respectivamente] na sociedade da época". ${ }^{60}$

E quais seriam os pontos de tensão entre Perón, Evita e sua própria base social? A historiografia, principalmente a marxista ou a herdeira desta tra-

\footnotetext{
58 PERÓN, s/d, p. 244.

59 Ibidem, p. 245.

${ }^{60}$ CAPELATO, Maria Helena Rolim, op. cit., p. 305. Em outras partes do livro a autora menciona que o discurso peronista nem sempre teve a mesma "receptividade". Capelato destaca, por exemplo, como o cinema foi um instrumento de divulgação do projeto político peronista. Perón aumentou as verbas para o cinema, a quantidade de filmes cresceu e, para proteger as produções argentinas, o governo colocou barreiras para as produções estrangeiras. Porém, o público teria sofrido uma drástica redução naqueles anos.
} 
dição, tende a privilegiar as greves como manifestações privilegiadas desta tensão. Sem desconsiderar a importância das greves, cabe não se restringir a elas, pois os trabalhadores não são compostos enquanto sujeitos apenas pela posição que ocupam no processo produtivo. Além disso, é preciso incorporar os sujeitos e grupos não diretamente ligados ao processo produtivo, igualmente alvos do discurso peronista. O peronismo defendia, por exemplo, as mulheres como mães e esposas, como pilares morais das famílias e estas, por sua vez, seriam as da sociedade. Nesse ponto, a presença de Eva Perón teria garantido uma particularidade ao peronismo, quando comparado, por exemplo, às demais experiências "populistas" da América Latina. Segundo Capelato, além da ideia de "salvação pelo poder masculino", Evita teria garantido ao peronismo a ideia da "redenção pelo poder feminino", traçando paralelos com Cristo e Maria, respectivamente. Capelato destaca que Perón e Evita dividiam a liderança do poder e desempenhavam funções específicas. “O presidente Perón, expressão do poder masculino, ativo, atuava na vida pública, exercendo atividades políticas bem definidas. Eva Perón, a mulher classicamente feminina, representava a intuição, o sentimento, a emoção".61 Em uma direção semelhante, Mariano Plotkin aponta que, para Perón, as mulheres eram importantes não apenas como eleitoras, mas também como mães e esposas, pois “(...) percibía a las mujeres como misionarias potenciales que podrían esparcir el mensaje peronista en los hogares (...)". ${ }^{62}$

Entretanto, o discurso peronista demonstra dificuldades para enraizar suas propostas em relação às mulheres. "Trabajan [as mulheres] casi como ellos. Prefieren, como ellos, la calle a la casa. No se resignan a ser madres, ni esposas". ${ }^{63}$ Existem tensões semelhantes - e não apenas em relação às mulheres - em temas como relacionamentos extraconjugais, dedicação ao trabalho, prudência nos gastos familiares, vícios, saúde, higiene, educação e produção cultural, dentre outros. ${ }^{64}$

Há no discurso de Evita um reconhecimento explícito de limites para se interferir principalmente na esfera privada. Ainda a respeito das mulheres, Eva

\footnotetext{
${ }^{61}$ Ibidem, p. 297.

62 PLOTKIN, Mariano Ben. Mañana es san Perón: propaganda, rituales políticos y educación en el régimen peronista (1946-1955). Caseros: Editorial de la Universidad Nacional de Tres de Febrero, 2007, p. 259.

63 PERÓN, 1996, p. XL.

${ }^{64}$ Cf. SILVA, Paulo Renato da. ¿Alpargatas si, libros no? Produção cultural e legitimidade política durante o governo de Perón (1946-1955). Tese de doutorado, História, Instituto de Filosofia e Ciências Humanas, Universidade Estadual de Campinas, 2009.
} 
Perón destaca que às “(...) portas do lar acaba a nação inteira e começam outras leis, outros direitos: a lei e o direito do homem, misto de amo e de ditador". ${ }^{65}$

Em Capelato e Plotkin, a forte presença e atuação de Eva Perón reforçaria o propósito peronista de transformar a sociedade argentina em uma "grande família", pautada pela unidade, mas também por princípios de hierarquia. Também consideramos que o propósito final era esse. No entanto, como acabamos de apontar, para que a sociedade fosse uma "grande família", o peronismo considerava necessário, também, transformar as famílias argentinas. Havia mudanças em curso, por exemplo, quanto ao papel das mulheres, que destoavam do discurso peronista. Acreditamos que a permanência do peronismo no cenário político e na memória dos argentinos interfere na análise da propaganda e do discurso de Perón e Evita, de tal forma que as tensões que destacamos acima ficam em segundo plano nas análises.

É necessário, portanto, não confundir a memória de Evita e do peronismo de uma maneira geral com as práticas dos setores populares durante o governo de Perón dos anos 1940 e 1950. Na passagem a seguir, além do evidente apelo emocional que remete ao melodrama recorrente na época, Evita, "profeticamente", destaca o poder muitas vezes regenerador da memória:

E talvez um dia, quando eu não mais exista, se venha a dizer de mim o que muitos filhos do povo dizem de suas mães, quando empreenderam a viagem definitiva:

"Sòmente [sic] agora avaliamos o quanto nos amava!".66

Assim, as tensões que indicamos no discurso de Evita sugerem que o fanatismo não se tornou a norma enquanto Perón esteve na presidência, apesar do constante apelo à família, à moral, ao nacionalismo e à religião, dentre outros valores considerados de grande ressonância nos setores populares. Pelo menos essa parece ter sido a percepção do governo em relação a sua própria base social. Essa constatação é fundamental para que a personagem histórica e o(s) mito(s) de Evita sejam analisados com as devidas particularidades.

\footnotetext{
${ }^{6}$ PERÓN, s/d, p. 285.

66 Ibid., p. 328.
} 


\section{Referências bibliográficas}

BLOCH, Marc. Introdução à história. Lisboa: Publicações Europa-América, 1976.

BOSOER, Fabián. Kirchner, segundo acto: el panorama electoral en Argentina. Nueva Sociedad, n 208, março-abril de 2007. Disponível em: < http://www.nuso. org/upload/articulos/3414_1.pdf>. Acesso em: 29/04/2012.

BURDMAN, Javier. La rearticulación identitaria del peronismo a partir del discurso de Carlos Menem. Una perspectiva desde los enfoques de Ernesto Laclau y Slavoj Zizek. Memoria y sociedad, Bogotá, no 25, v. 12, jul.-dez. 2008. Disponível em:<http://memoriaysociedad.javeriana.edu.co/anexo/articulo/doc/d42_25_1. pdf>. Acesso em: 28/04/2012.

CAPELATO, Maria Helena Rolim. Multidões em cena: propaganda política no varguismo e no peronismo. $2^{\mathrm{a}}$ ed. São Paulo: Editora Unesp, 2009.

Dirigentes peronistas y opositores recordaron la figura de Eva Perón. La Nación, Buenos Aires, 27/07/2004. Disponível em: <http://www.lanacion.com.ar/622226dirigentes-peronistas-y-opositores-recordaron-la-figura-de-eva-peron $>$. Acesso em: 14/05/2012.

DOMÍNGUEZ, Nora. Los rostros de Eva Perón. In: SORIA, Claudia, ROCCA, Paola Cortés e DIELEKE, Edgardo (org.). Políticas del sentimiento: el peronismo y la construcción de la Argentina moderna. Buenos Aires: Prometeo Libros, 2010.

Estreno con ruido de la Evita de Madonna y Parker. Clarín, Buenos Aires, 18/02/1997. Disponível em: <http://edant.clarin.com/diario/1997/02/18/e-03001d.htm>. Acesso em: 28/04/2012.

Eva Perón. Cuadernos de Crisis, Buenos Aires, nº 7, 1974.

FEINMANN, José Pablo. Los libros de la Libertadora. Página/12, Buenos Aires, 04/05/2008. Disponível em:<http://www.pagina12.com.ar/especiales/archivo/ peronismo_feinmann/CLASE24.pdf $>$. Acesso em: 23/10/2013.

KIRCHNER, Cristina. Acto de inauguración del retrato de Evita en el ex-Ministerio de Obras Públicas: Palabras de la presidenta de la Nación. Disponível em: $<$ http://www.presidencia.gov.ar/discursos/25273>. Acesso em: 23/04/2012.

NEIBURG, Federico. Os intelectuais e a invenção do peronismo. São Paulo: Edusp, 1997.

NORA, Pierre. Entre memória e história: a problemática dos lugares. Projeto História, São Paulo, nº 10, dez. 1993.

PERÓN, Eva. A razão de minha vida. Rio de Janeiro: Freitas Bastos, s/d.

PERÓN, Eva. Por qué soy peronista y las fuerzas espirituales del peronismo. Buenos Aires: C. S. Ediciones, 1996.

MAIN, Mary. La mujer del látigo. 5ª ed. Buenos Aires: Ediciones La Reja, 1956.

MENEM, Carlos Saúl. Prólogo. In: PERÓN, Juan Domingo. Doctrina peronista. Buenos Aires: C. S. Ediciones, 1996.

PLOTKIN, Mariano Ben. Mañana es san Perón: propaganda, rituales políticos y educación en el régimen peronista (1946-1955). Caseros: Editorial de la Universidad Nacional de Tres de Febrero, 2007. 
ROSANO, Susana. El paraíso perdido del peronismo, en clave hermética (Algunos apuntes para pensar la obra de Daniel Santoro). Disponível em: $<$ http://www. unsam.edu.ar/home/material/rosano.pdf $>$. Acesso em: 29/04/2012.

SARLO, Beatriz. A paixão e a exceção: Borges, Eva Perón, Montoneros. São Paulo: Companhia das Letras; Belo Horizonte: Editora UFMG, 2005.

SEBRELI, Juan José. Eva Perón ¿aventurera o militante? 4ª ed. Buenos Aires: La Pléyade, 1971.

SIGAL, Silvia e VERÓN, Eliseo. Perón o muerte: los fundamentos discursivos del fenómeno peronista. Buenos Aires: Legasa, 1986.

SILVA, Paulo Renato da. ¿Alpargatas si, libros no? Produção cultural e legitimidade política durante o governo de Perón (1946-1955). Tese de doutorado, História, Instituto de Filosofia e Ciências Humanas, Universidade Estadual de Campinas, 2009.

SOLANAS, Fernando Pino. Aniversario del fallecimiento de Eva Perón. Disponível em: <http://es-es.facebook.com/notes/fernando-pino-solanas/aniversariodel-fallecimiento-de-eva-peron/137880766242774>. Acesso em: 23/04/2012.

TAYLOR, Julie M. Evita Perón: los mitos de una mujer. Buenos Aires: Editorial de Belgrano, 1981.

Un recuerdo. Clarín, Buenos Aires, 27/07/2000. Disponível em: $<$ http://edant.clarin. com/diario/2000/07/27/p-00902.htm>. Acesso em: 14/05/2012.

Una misa que sorprendió a todos. Clarín, Buenos Aires, 27/07/2000. Disponível em: <http://edant.clarin.com/diario/2000/07/27/p-00302.htm>. Acesso em: 14/05/2012.

VIDAL, Armando. Eva Perón fue una reina de verdad y no una reina del bótox. Clarín, Buenos Aires, 12/10/2007. Disponível em: <http://edant.clarin.com/ diario/2007/10/12/elpais/p-01201.htm>. Acesso em: 23/04/2012. 
